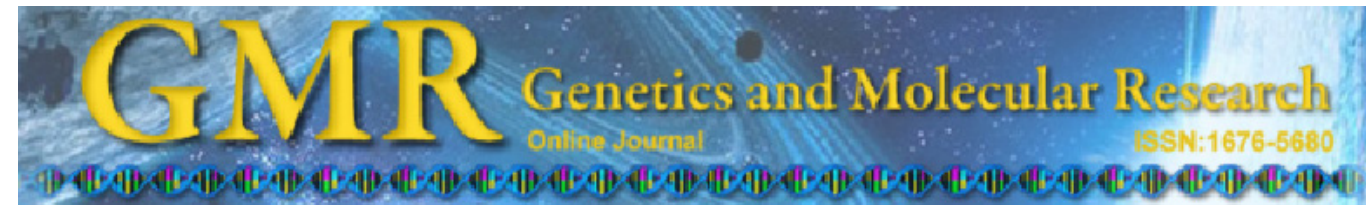

\title{
Eucalyptus growth promotion by endophytic Bacillus spp
}

\author{
I.C.P. Paz ${ }^{1}$, R.C.M. Santin ${ }^{1}$, A.M. Guimarães ${ }^{1}$, O.P.P. Rosa ${ }^{3}$, \\ A.C.F. Dias ${ }^{2}$, M.C. Quecine ${ }^{2}$, J.L. Azevedo ${ }^{2}$ and A.T.S. Matsumura ${ }^{1}$ \\ ${ }^{1}$ Laboratório de Microbiologia Fitopatógica, \\ Universidade Federal do Rio Grande do Sul, Porto Alegre, RS, Brasil \\ 2Departamento de Genética, Escola Superior de Agricultura "Luiz de Queiroz", \\ Universidade de São Paulo, Piracicaba, SP, Brasil \\ ${ }^{3}$ Tecnoplanta Florestal, Barra do Ribeiro, RS, Brasil \\ Corresponding author: I.C.P. Paz \\ E-mail: isapaz@gmail.com
}

Genet. Mol. Res. 11 (4): 3711-3720 (2012)

Received November 1, 2011

Accepted March 12, 2012

Published August 17, 2012

DOI http://dx.doi.org/10.4238/2012.August.17.9

\begin{abstract}
Clonal eucalyptus plantings have increased in recent years; however, some clones with high production characteristics have vegetative propagation problems because of weak root and aerial development. Endophytic microorganisms live inside healthy plants without causing any damage to their hosts and can be beneficial, acting as plant growth promoters. We isolated endophytic bacteria from eucalyptus plants and evaluated their potential in plant growth promotion of clonal plantlets of Eucalyptus urophylla $\mathrm{x}$ E. grandis, known as the hybrid, E. urograndis. Eighteen isolates of E. urograndis, clone 4622, were tested for plant growth promotion using the same clone. These isolates were also evaluated for indole acetic acid production and their potential for nitrogen fixation and phosphate solubilization. The isolates were identified by partial sequencing of $16 \mathrm{~S}$ rRNA. Bacillus subtilis was the most prevalent species. Several Bacillus species, including B. licheniformis and B. subtilis, were found for the first time as endophytes of eucalyptus. Bacillus sp strain EUCB 10 significantly increased the growth of the root and aerial parts of eucalyptus plantlets
\end{abstract}


under greenhouse conditions, during the summer and winter seasons.

Key words: Plant-growth promotion; Endophytic microorganism; Rooting; Eucalyptus

\section{INTRODUCTION}

Endophytes are culturable and non-culturable microorganisms that reside within healthy plants without causing any damage (Azevedo et al., 2000; Azevedo and Araújo, 2007) and, in many cases, may prove beneficial to their host plants. Endophytic microorganisms exhibit agricultural potential as plant growth promoters, mainly by providing beneficial compounds for the plant host (Strobel, 2002; Kuklinsky-Sobral et al., 2004; Berg and Hallmann, 2006; Long et al., 2008). However, the growth-promoting effect of endophytes is dependent on the associated microbial community and the specific plant genotype, which should be investigated in each case (Bruneta et al., 2007).

Clonal-intensive forestry of eucalyptus frequently uses vegetative propagation of superior genetic materials, allowing the optimization of the production of plantlets that retain the favorable characteristics of the plants and avoid seedling variability by open breeding. However, this type of plant propagation poses certain problems, including variable results in the rooting index of cuttings and diseases acquired during this process (Díaz et al., 2009; Lombard et al., 2010).

Many studies have shown evidence of the benefits of endophytic microorganisms in eucalyptus plantlets; for instance, they have been shown to increase the rooting indexes and vegetative biomass or act as biocontrol agents in improving plant resistance when challenged with different pathogens (Mafia et al., 2005; Ferreira et al., 2008; Procópio et al., 2009). The present study involved the isolation of endophytic bacteria from eucalyptus and the evaluation of their potential for root and aerial growth promotion in clonal plantlets of Eucalyptus urograndis.

\section{MATERIAL AND METHODS}

\section{Bacterial isolation}

The endophytic bacterial isolates were obtained according to the method used by Procópio et al. (2009). The E. urophylla x E. grandis hybrids were located in Guaíba, Rio Grande do Sul State, Brazil $\left(30^{\circ} 13^{\prime} 37.57^{\prime \prime S}, 51^{\circ} 31^{\prime} 58.31^{\prime \prime W}\right)$. Stem and leaf samples were randomly collected from 3-year-old trees and immediately stored at $4^{\circ} \mathrm{C}$. All samples were processed within $24 \mathrm{~h}$. The samples were washed under running tap water and cut into pieces approximately $5 \mathrm{~mm}$ in diameter. The fragments were surface-sterilized by dipping them in 70\% ethanol for $1 \mathrm{~min}$ and $2 \%$ sodium hypochlorite for $3 \mathrm{~min}$, and they were rinsed in sterile distilled water 3 times. Aliquots of the water from the final rinsing solutions were plated on the same media used for the fragments (Procópio et al., 2009). Five leaves and stem pieces were placed on each Petri dish containing Trypic Soy agar media amended with $2 \%$ polyvinylpyrrolidone. The Petri dishes were incubated at $28^{\circ} \mathrm{C}$ for 7 days and checked every day. The number of pieces containing bacterial isolates was counted, and the frequen- 
cy of endophytic bacteria in the plant fragments was measured by the following formula: the ratio of the number of fragments showing bacterial growth to the total of number of plated fragments. The product of this ratio and 100 was calculated as the percentage of fragments with the bacteria.

\section{Identification of bacterial isolates}

Genomic DNA was extracted from the isolated endophytic bacteria by using the following protocol. Two milliliter of overnight liquid bacterial culture was centrifuged for 5 min at $12,000 \mathrm{~g}$ and resuspended in $500 \mu \mathrm{L}$ TE buffer $(10 \mathrm{mM}$ Tris- $\mathrm{HCl}, 1 \mathrm{mM}$ EDTA, $\mathrm{pH}$ 8.0 ), recentrifuged, decanted, and resuspended in $500 \mu \mathrm{L}$ TE buffer plus, $0.5 \mathrm{~g}$ glass beads $(0.1 \mathrm{~mm}$ in diameter) and $15 \mu \mathrm{L} 20 \%$ sodium dodecyl sulfate. The cells were homogenized for $1 \mathrm{~min}$ in a bead beater (Braun cell homogenizer; B. Braun, Germany). Tris-buffered phenol $(500 \mu \mathrm{L})$ was added, and the solution was mixed well and centrifuged for 5 min at $12,000 \mathrm{~g}$. The aqueous phase was extracted once with phenol-chloroform $(1: 1)$ and once with chloroform, and the DNA was precipitated with $\mathrm{NaCl}(0.1, \mathrm{v} / \mathrm{v})$ and isopropanol $(0.6$, $\mathrm{v} / \mathrm{v})(3 \mathrm{~min}$ at room temperature) and then collected by centrifugation (10 $\mathrm{min}$ at 12,000 $\mathrm{g}$ ). The pellet was washed with $70 \%$ ethanol, air-dried, and resuspended in $50 \mu \mathrm{L}$ Milli-Q water. The total DNA was analyzed by electrophoresis by spotting $4 \mu \mathrm{L}$ of the mixture onto $1 \%$ agarose gel and visualized under ultraviolet light after staining with $1 \%$ ethidium bromide in $1 \mathrm{X}$ TAE buffer ( $40 \mathrm{mM}$ Tris-acetate; $1 \mathrm{mM}$ EDTA), according to the method described by Sambrook et al. (1989).

The diversity of the culturable bacterial isolates was studied by partial sequencing of the 16S rDNA gene. PCR was conducted in a 50- $\mu$ L reaction volume containing $0.5-10$ $\mu \mathrm{g}$ DNA, $0.2 \mu \mathrm{M}$ of each primer (R1378: 5'-CGGTGTGTACAAGGCCCGGGAACG-3' and PO27F: 5'-GAGAGTTTGATCCTGGCTCAG-3'), $0.2 \mathrm{mM}$ of each dNTP, $3.75 \mathrm{mM} \mathrm{MgCl}$, $0.05 \mathrm{U}$ Taq DNA polymerase (Invitrogen, Brazil) in $20 \mathrm{mM}$ Tris- $\mathrm{HCl}, \mathrm{pH} 8.3$, and $50 \mathrm{mM}$ $\mathrm{KCl}$. The amplification protocol consisted of an initial step at $94^{\circ} \mathrm{C}$ for $4 \mathrm{~min}$, followed by 35 amplification cycles of $94^{\circ} \mathrm{C}$ for $30 \mathrm{~s}, 63^{\circ} \mathrm{C}$ for $1 \mathrm{~min}$, and $72^{\circ} \mathrm{C}$ for $1 \mathrm{~min}$, with a final extension at $72^{\circ} \mathrm{C}$ for $10 \mathrm{~min}$. The $16 \mathrm{~S}$ rRNA gene PCR products were purified by the polyethylene glycol method described by Lis (1980) and sequenced at Instituto do Genoma Humano (USP, São Paulo, Brazil). The sequences were evaluated in BLAST-N (Altschul et al., 1990) against the database of the GenBank Development [National Center for Biotechnology Information website and RDPQuery (Dyszynski and Sheldon, 2011)].

Phylogenetic relationships among the sequences of the isolates and the reference-species were inferred using the neighbor-joining method (Saitou and Nei, 1987). The evolutionary distances were computed using the two-parameter method (Kimura, 1980). Both analyses were performed using the MEGA 4 program (Tamura et al., 2007).

\section{Indole acetic acid (IAA) production}

IAA production was evaluated using the Patten and Glick (2002) method. First, the bacterial isolates were inoculated in $10 \%$ Tryptone Soy broth medium supplemented with Ltryptophan $(5 \mathrm{mM})$ and incubated at $28^{\circ} \mathrm{C}$ for $24 \mathrm{~h}$ in the dark. Triplicate cultures were then 
centrifuged ( $5 \mathrm{~min}, 7000 \mathrm{~g}$, at room temperature), and $1.5 \mathrm{~mL}$ Salkowski reagent (Patten and Glick, 2002) was added to $1.5 \mathrm{~mL}$ of the supernatant. This mixture was incubated for $20 \mathrm{~min}$ in the dark at room temperature and analyzed using a spectrophotometer $(520 \mathrm{~nm}$; Ultrospec 3000, Amersham-Pharmacia Biotech). The absorbance values obtained were interpolated in a standard curve to determine the IAA concentration $\left(r^{2}=0.9867\right)$.

\section{Phosphate solubilization}

The ability of the bacterial strains to solubilize inorganic phosphate was evidenced by a halo obtained after cultivation of the culture medium supplemented with $\mathrm{Ca}_{3}\left(\mathrm{PO}_{4}\right)_{2}$ according to the method described by Nautiyal (1999). The evaluation of the presence of a halo around the bacterial colony was observed after 7 days of incubation at $28^{\circ} \mathrm{C}$.

\section{Biological fixation of atmospheric nitrogen}

The ability to fix atmospheric nitrogen was evaluated according to the method described by Döbereiner et al. (1995). The isolates were inoculated in tubes containing $10 \mathrm{~mL}$ semi-solid NFb medium $\left(5 \mathrm{~g} / \mathrm{L}\right.$ malic acid; $0.5 \mathrm{~g} / \mathrm{L} \mathrm{K}_{2} \mathrm{HPO}_{4} ; 0.2 \mathrm{~g} / \mathrm{L} \mathrm{MgSO}_{4} .7 \mathrm{H}_{2} \mathrm{O} ; 0.1 \mathrm{~g} / \mathrm{L}$ $\mathrm{NaCl} ; 0.01 \mathrm{~g} / \mathrm{L} \mathrm{CaCl}_{2} .2 \mathrm{H}_{2} \mathrm{O} ; 4 \mathrm{~mL} 1.64 \%$ Fe-EDTA); $2 \mathrm{~mL} 0.5 \%$ bromothymol blue; $2 \mathrm{~mL}$ micronutrients $\left(0.2 \mathrm{~g} / \mathrm{L} \mathrm{Na}_{2} \mathrm{MoO}_{4} \cdot 2 \mathrm{H}_{2} \mathrm{O} ; 0.235 \mathrm{~g} / \mathrm{L} \mathrm{MnSO}_{4} \cdot \mathrm{H}_{2} \mathrm{O} ; 0.28 \mathrm{~g} / \mathrm{L} \mathrm{H}_{3} \mathrm{BO}_{3} ; 0.008 \mathrm{~g} / \mathrm{L}\right.$ $\mathrm{CuSO}_{4} .5 \mathrm{H}_{2} \mathrm{O}$ ), and $1.75 \mathrm{~g} / \mathrm{L}$ agar. Bacterial growth was evaluated after $72 \mathrm{~h}$ of incubation at $28^{\circ} \mathrm{C}$ in the dark. The formation of a growth disc in the culture medium indicated atmospheric nitrogen fixation by the bacterial isolates.

\section{Plant growth promotion assay}

Eight isolates were selected for in vivo assays on the basis of the results obtained from in vitro assays of the production of IAA and their ability to make nitrogen available through biological fixation and phosphate solubilization; the selected isolates were Bacillus spp EUCB1, 2, 10, 13, 21, 25, 26, and 28 and Pseudomonas sp EUCB 3 was used as the negative control.

Twenty-five E. urograndis cuttings per isolate were immersed for $1 \mathrm{~h}$ in the bacterial suspension $\left(10^{3} \mathrm{CFU} / \mathrm{mL}\right)$ and were planted in burned rice coat and vermiculite (1:1) substrate, according to the method described by Procópio (2004). The rooting percentage, the lengths of the root and aerial part, and dried weight were evaluated. The experiments were conducted in the summer of 2008. In the same year, the most promising isolate was tested again in the winter season, and the seedling quality index, proposed by Dickson et al. (1960), was calculated.

\section{Statistical analysis}

Data analysis was performed with the SPSS 16.0 package. A completely random design was used for all the assays. The values showed the percentage, which were then arcosen transformed by $\sqrt{ } \mathrm{X} / 100$ to normalize the data. All data were analyzed for significance $(\mathrm{P}>$ 0.05 ) using Tukey and Scott-Knott tests. 


\section{RESULTS AND DISCUSSION}

Differences between the tissues in the number of isolates per fragment were determined. The percentage of endophytic bacteria isolated from the stems was $10.6 \%$ and that from leaf fragments, was $1.19 \%$. No bacteria were observed on the plates used to confirm superficial disinfection.

Studies showing the spatial distribution of endophytic fungi inside the plants are common (Verma et al., 2007), and the preferences of the fungi for host, tissue, and light, among other factors, have been verified (Unterseher et al., 2007). These preferences may differ even in different areas of the same tissue (Rodriguez et al., 2009). A similar phenomenon is possibly true for endophytic bacteria. Some Eucalyptus species seem to be more thickly colonized by endophytic bacteria than others, as verified by Procópio et al. (2009). The authors also observed a low-isolation frequency in a different clone of E. urophylla $\mathrm{x}$ E. grandis hybrid, suggesting that these differences occur due to a variation in the phenolic compounds and essential oils among Eucalyptus species.

The bacterial isolates obtained in the present study were identified using the partial sequence of $16 \mathrm{~S}$ rDNA analyses. The majority of the isolates were not identified at the species level: $61 \%$ Bacillus sp, followed by Bacillus subtilis (16\%). One strain was identified as Bacillus pumilus (EUCB 1); another, as Bacillus licheniformis (EUCB 5), and a third, as Pseudomonas sp (EUCB 3), which was the only one isolated from leaves (Table 1). The genus Bacillus was also the main group found by Ferreira et al. (2008) who isolated endophytic bacteria from eucalyptus seeds. Moreover, Pseudomonas and Bacillus spp are found as endophytes in several other plant species (Chanway, 1998; Araújo et al., 2002; Nunes, 2004).

\begin{tabular}{|c|c|c|c|}
\hline Isolates & Identification & Similarity (\%) & Bacterial species (\%) \\
\hline EUCB 3* & Pseudomonas sp & 89 & 4.76 \\
\hline EUCB 1 & Bacillus pumilus & 96 & 4.76 \\
\hline EUCB 2 & Bacillus sp & 97 & 60.1 \\
\hline EUCB 4 & Bacillus sp & 98 & \\
\hline EUCB 6 & Bacillus sp & 100 & \\
\hline EUCB 10 & Bacillus sp & 96 & \\
\hline EUCB 13 & Bacillus sp & 98 & \\
\hline EUCB 14 & Bacillus sp & 91 & \\
\hline EUCB 15 & Bacillus sp & 88 & \\
\hline EUCB 21 & Bacillus $\mathrm{sp}$ & 98 & \\
\hline EUCB 24 & Bacillus sp & 98 & \\
\hline EUCB 25 & Bacillus $\mathrm{sp}$ & 98 & \\
\hline EUCB 27 & Bacillus sp & 98 & \\
\hline EUCB 28 & Bacillus $\mathrm{sp}$ & 96 & \\
\hline EUCB 7 & Bacillus subtilis & 96 & 16.6 \\
\hline EUCB 8 & Bacillus subtilis & 92 & \\
\hline EUCB 26 & Bacillus subtilis & 98 & \\
\hline EUCB 5 & Bacillus licheniformis & 98 & 4.76 \\
\hline
\end{tabular}

*EUCB 3 was the only bacterium isolated from eucalyptus leaves.

EUCB 10, 13, 15, 25, 26, and 28 belonged to the same clade of $B$. subtilis reference strains. Similarly, the isolates EUC 8, 14, and 24 showed a high similarity with B. pumilus reference strains (Figure 1). Our dendrogram suggests a possible identification of the isolates described as Bacillus sp by the NCBI BlastN analysis. Chun and Bae (2000) suggest the 
phylogentic analysis of Bacillus taxa using the gyrA gene instead of 16S rDNA. The Bacillus classification system has been frequently modified, complicating its correct identification.

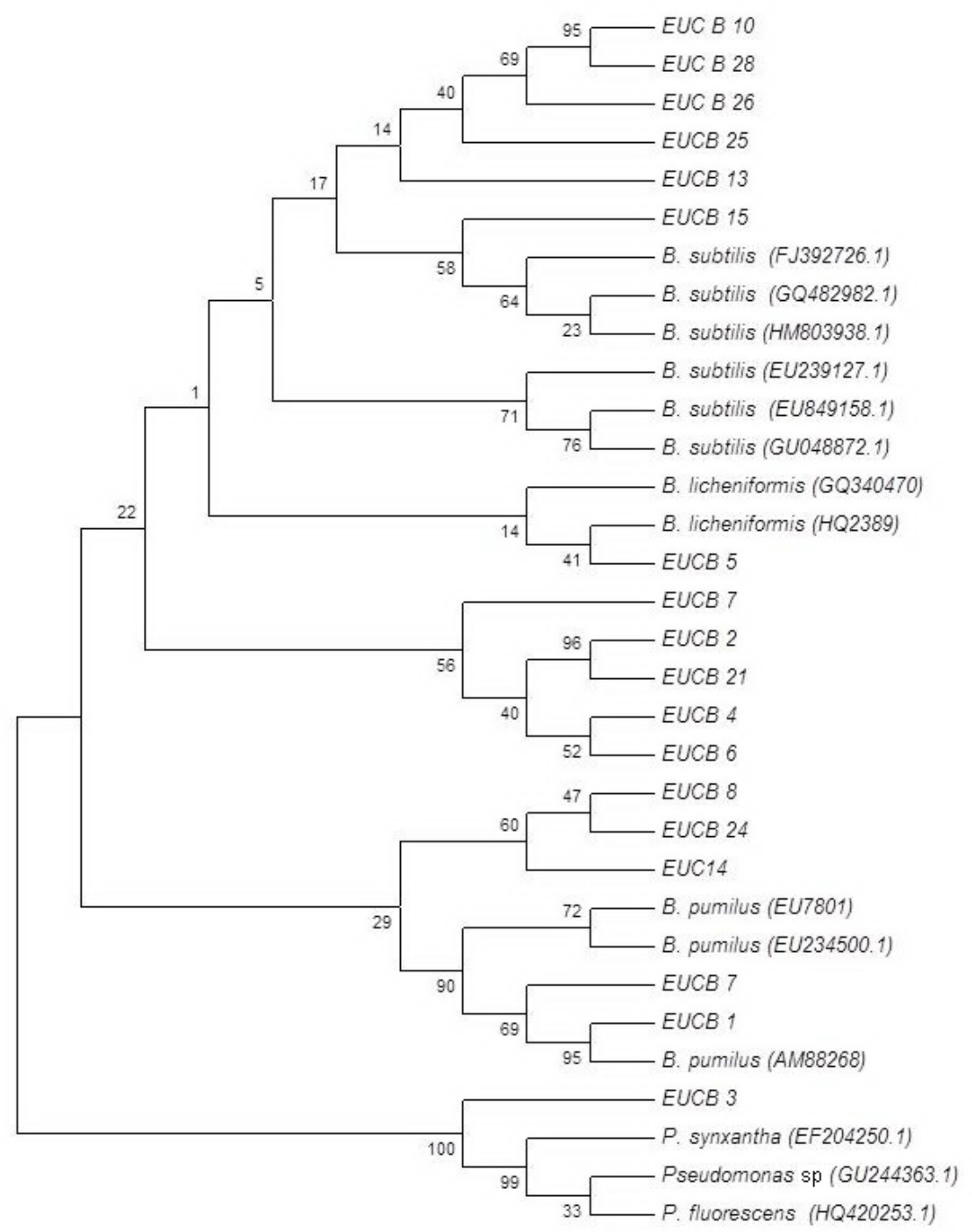

Figure 1. Phylogenetic dendrogram of endophytic strain from Eucalyptus urograndis plantlets and selected reference sequences. Sequences of $>1500$ nucleotides $16 \mathrm{~S}$ rDNA were aligned using the Clustal $\mathrm{W}$ and phylogenic tree constructed using neighbor joining (MEGA 4.1). Sequence references exported from Gene Bank (NCBI) are indicated by reference numbers (1000 replicates). The scale bar indicates 0.02 inferred nucleotide substitutions per position.

The low diversity of the species detected among the bacterial isolates from E. urophylla $\mathrm{x}$ E. grandis does not necessarily represent the actual diversity of endophytic microorganisms associated with Eucalyptus spp. The isolation method using plant fragments was ad- 
opted to select isolates with faster and easier growth for the purpose of discovering potentially beneficial bacteria for mass use in greenhouses and not the characterization of an endophytic bacterial community associated with the E. urophylla $\mathrm{x}$ E. grandis hybrid.

Ferreira et al. (2008) detected a high frequency of endophytic isolates of the Bacillaceae family, suggesting that this group may be adapted to the interior of eucalyptus plants and reside systemically in this host. However, different species of Bacillus apparently have different preferential niches inside the plant host. We isolated B. subtilis and B. licheniformis from the eucalyptus stem, but this species was not found by Ferreira (2008) as an endophyte of roots or on eucalyptus stems by Procópio et al. (2009). B. pumilus was detected as an endophyte in the aerial part of eucalyptus in this study, but only as an endophyte from roots by Ferreira (2008). Interestingly, the same authors did not find B. pumilus in the rhizoplane, suggesting that this species could be transmitted by seed, but when evaluating the endophytic communities of eucalyptus seeds from different species they did not find B. pumilus. Probably, the stomata and hidathodes serve as a gateway to B. pumilus isolates in the aerial part of eucalyptus found in the present study.

From the 18 bacterial isolates obtained in the present study, 7 were selected due to important characteristics pre-assayed in vitro; they include EUCB 2, 10, 13 21, 25, 26, and 28. One isolate was selected by neutral activity for use as a positive control (Pseudomonas sp EUCB 3 ) to evaluate the activity of this endophyte in rooting and growth promotion in E. urophylla $\times$ E. grandis hybrid plantlets (Table 2). None of the other isolates showed any related plant growth promotion activity, such as phosphate solubilization, IAA production, or biological nitrogen fixation. From the 18 isolates, only $4(22 \%)$ were able to solubilize phosphate, 7 (38\%) showed an ability for biological nitrogen fixation, and $8(44 \%)$ were able to produce IAA (Table 2).

Table 2. Phosphate solubilization, atmospheric nitrogen fixation and indole acetic acid (IAA) production by endophytic bacteria from Eucalyptus urograndis hybrid.

\begin{tabular}{lccc}
\hline Isolates & Phosphate solubilization & Atmospheric nitrogen fixation & IAA $(\mu \mathrm{g} / \mathrm{mL})^{*}$ \\
\hline EUCB 2 & - & + & $26.4^{\mathrm{bc}}$ \\
EUCB 3 & - & + & $21.7^{\mathrm{abc}}$ \\
EUCB 10 & + & + & $24.5^{\mathrm{abc}}$ \\
EUCB 13 & - & - & $22.1^{\mathrm{abc}}$ \\
EUCB 21 & - & + & $19.9^{\mathrm{abc}}$ \\
EUCB 25 & + & + & $23.3^{\mathrm{abc}}$ \\
EUCB 26 & + & + & $27.5^{\mathrm{c}}$ \\
EUCB 28 & + & + & $17.1^{\mathrm{a}}$ \\
\hline
\end{tabular}

$(-)=$ no degradation/growth halo production; $(+)=$ degradation/growth halo production. $*$ The values are the average of four replicates. Values in the same column, followed by the same superscript letters did not differ according to the Tukey test $(\mathrm{P}>0.05)$.

During the experiment on plant growth promotion, the responses to bacterial inoculation differed with the isolates tested (Table 3). Among the isolates tested, only EUCB 10 significantly increased the rooting index (96.2\%). However, EUCB 21 and 1 showed an increase in the rooting index with 93 and $92.9 \%$, respectively. EUCB 2, 25, 26, and 28 showed a significant negative effect on eucalyptus rooting comparing to the control treatment. Their rooting indexes were $81.2,77,79.8$, and $75.7 \%$, respectively. We observed that the cuttings treated with EUCB 13 showed increased length of the aerial part, but the greatest activity occurred in the root system. This isolate promoted a significant increase of $24.8 \%$ in root length (Table 3 ). 


\begin{tabular}{|c|c|c|c|c|c|c|c|}
\hline \multirow[t]{3}{*}{ Isolates } & \multirow[t]{3}{*}{ Rooting (\%)* } & \multicolumn{4}{|c|}{ Dry weight $(\mathrm{g})^{*}$} & \multicolumn{2}{|c|}{ Length $(\mathrm{cm})$} \\
\hline & & \multicolumn{2}{|c|}{ Aerial part } & \multicolumn{2}{|c|}{ Root system } & \multirow[t]{2}{*}{ Aerial part } & \multirow[t]{2}{*}{ Root system } \\
\hline & & 30 days & 80 days & 30 days & 80 days & & \\
\hline Control & $89.4^{\mathrm{b}}$ & $3.29^{\mathrm{b}}$ & $7.35^{\mathrm{a}}$ & $0.59^{\mathrm{b}}$ & $2.90^{\mathrm{a}}$ & $14.8^{\mathrm{ab}}$ & $12.66^{\mathrm{a}}$ \\
\hline EUCB 1 & $92.9^{\mathrm{b}}$ & $3.59^{\mathrm{b}}$ & $5.18^{\mathrm{b}}$ & $0.73^{\mathrm{a}}$ & $2.19^{\mathrm{b}}$ & $14.05^{\mathrm{abcd}}$ & $13.68^{\mathrm{ab}}$ \\
\hline EUCB 2 & $81.2^{\mathrm{c}}$ & $3.41^{\mathrm{b}}$ & $5.24^{\mathrm{b}}$ & $0.54^{\mathrm{b}}$ & $2.13^{\mathrm{b}}$ & $13.72^{\text {bcd }}$ & $13.36^{\mathrm{ab}}$ \\
\hline EUCB 3 & $91^{\mathrm{b}}$ & $2.82^{\mathrm{c}}$ & $2.50^{\mathrm{c}}$ & $0.58^{\mathrm{a}}$ & $1.38^{\mathrm{c}}$ & $13.3^{\mathrm{e}}$ & $12.74^{\mathrm{a}}$ \\
\hline EUCB 10 & $96.2^{\mathrm{a}}$ & $3.29^{\mathrm{b}}$ & $7.70^{\mathrm{a}}$ & $0.73^{\mathrm{a}}$ & $3.03^{\mathrm{a}}$ & $13.96^{\mathrm{abcd}}$ & $13.19^{\mathrm{ab}}$ \\
\hline EUCB 13 & $90^{\mathrm{b}}$ & $4.13^{\mathrm{a}}$ & $6.12^{\mathrm{a}}$ & $0.80^{\mathrm{a}}$ & $2.76^{\mathrm{a}}$ & $15.47^{\mathrm{a}}$ & $15.8^{\mathrm{b}}$ \\
\hline EUCB 21 & $93^{\mathrm{b}}$ & $3.41^{\mathrm{b}}$ & $5.80^{\mathrm{b}}$ & $0.71^{\mathrm{a}}$ & $2.92^{\mathrm{a}}$ & $14.51^{\mathrm{abc}}$ & $15.8^{\mathrm{b}}$ \\
\hline EUCB 25 & $77^{\mathrm{c}}$ & $3.43^{\mathrm{b}}$ & $7.26^{\mathrm{a}}$ & $0.87^{\mathrm{a}}$ & $2.55^{\mathrm{a}}$ & $13.1^{\text {bcde }}$ & $14.5^{\mathrm{ab}}$ \\
\hline EUCB 26 & $79.8^{c}$ & $2.59^{\mathrm{c}}$ & $1.96^{\mathrm{c}}$ & $0.43^{\mathrm{b}}$ & $0.63^{\mathrm{c}}$ & $12.4^{\mathrm{de}}$ & $12.7^{\mathrm{a}}$ \\
\hline EUCB 28 & $75.7^{\mathrm{c}}$ & $2.68^{\mathrm{c}}$ & $3.91^{\mathrm{b}}$ & $0.54^{\mathrm{b}}$ & $1.61^{\mathrm{c}}$ & $12.9^{\text {cde }}$ & $12.6^{\mathrm{a}}$ \\
\hline
\end{tabular}

*The values are the average of 25 replicates per isolate. Values in the same column, followed by the same superscript letters did not differ according to the Tukey test $(\mathrm{P}>0.05)$.

Plant growth promotion by the Bacillus species has already been described by other authors (Wang et al., 2009; Dias et al., 2009). The action is more evident in the root system, which is probably due to auxin production by bacterial isolates. Shi et al. (2009) found a positive correlation between IAA and the length and fresh weight of sugar beet roots, with the optimal concentration ranging between 31.23 and $39.12 \mu \mathrm{g} / \mathrm{mL}$ IAA, in culture. However, the strain EUCB 26, which showed a high production of IAA, had a negative effect on eucalyptus rooting as well as a negative effect on the weight and length of the plant, thereby suggesting a negative correlation between this isolate and the eucalyptus plant. Dias et al. (2009) also verified negative correlations between Bacillus endophytic bacteria and host plants in strawberries.

Plant growth promotion by endophytic bacteria could be mediated by different mechanisms, such as the production of phytohormones and siderophores; the biological fixation of nitrogen; phosphate solubilization, or enzymatic activity, such as ethylene suppression by aminocyclopropane-1-carboxylic acid deaminase (Berg and Hallmann, 2006).

Among the isolates tested, EUCB 10, 25, 26, and 28 could solubilize phosphate and had the ability for the biological fixation of nitrogen (Table 2). However, these effects could not be correlated with an increase in the plant's length and dry weight, except in the case of EUCB 10, which significantly promoted the rooting as well as the increase in the radicular biomass. On the basis of the results obtained in the summer, EUCB 10 was selected as the most promising plant growth promoter and was re-evaluated during the winter season.

Many characteristics of the plantlets were evaluated, and one index of plantlet quality (Dickson et al., 1960) was applied for better assessment of the effects of EUCB 10 on plant growth promotion in eucalyptus. Again, EUCB 10 showed a significantly positive effect on inoculated plants (index of 0.231 against 0.171 in control plants; $\mathrm{P} \leq 0.05$ ). Analysis of the individual parameters confirmed the significant positive effects of the EUCB 10 on eucalyptus plants, but no effect was noted on the plant's height (Table 4).

From the results of this study, we concluded that the endophytic bacteria from the $E$. urophylla $\mathrm{x}$ E. grandis hybrid are promising microorganisms for promoting rooting and plant growth among clonal plantlets. However, further evaluation of the commercial application of the effectiveness of these strains and the designing of an inoculating formulation and application must be conducted under field conditions. 


\begin{tabular}{|c|c|c|}
\hline \multirow[t]{2}{*}{ Characteristics } & \multicolumn{2}{|c|}{ Treatment* } \\
\hline & Control & EUCB 10 \\
\hline Height $(\mathrm{cm})$ & $29.64^{\mathrm{a}}$ & $29.94^{\mathrm{a}}$ \\
\hline Dried weight of aerial part $(\mathrm{g})$ & $1.19^{\mathrm{a}}$ & $1.48^{\mathrm{b}}$ \\
\hline Dried weight of radicular system $(\mathrm{g})$ & $0.57^{\mathrm{a}}$ & $0.751^{\mathrm{b}}$ \\
\hline Diameter of stem (mm) & $3.59^{\mathrm{a}}$ & $3.86^{\mathrm{b}}$ \\
\hline Number of leaves & $9.58^{\mathrm{a}}$ & $10.68^{\mathrm{b}}$ \\
\hline
\end{tabular}

*The values are the average of 25 replicates. Values in the same row, followed by the same superscript letters did not differ by the Tukey test $(\mathrm{P}>0.05)$.

\section{ACKNOWLEDGMENTS}

in this experiment.

\section{REFERENCES}

Altschul SF, Gish W, Miller W, Myers EW, et al. (1990). Basic local alignment search tool. J. Mol. Biol. 215: 403-410.

Araújo WL, Marcon J, Maccheroni W Jr, Van Elsas JD, et al. (2002). Diversity of endophytic bacterial populations and their interaction with Xylella fastidiosa in citrus plants. Appl. Environ. Microbiol. 68: 4906-4914.

Azevedo JL and Araújo WL (2007). Diversity and Applications of Endophytic Fungi Isolated from Tropical Plants. In: Fungi: Multifaceted Microbes (Guangui BN and Deshmukh SK, eds.). Anamaya Publishers New Delhi and CRC Press, Boca Raton, 189-207.

Azevedo JL, Maccheroni W Jr, Pereira JO and Araújo WL (2000). Endophytic microorganisms: a review on insect control and recent advances on tropical plants. Electronic. J. Biotechnol. 3: 40-65.

Berg G and Hallmann J (2006). Control of Plant Pathogenic Fungi with Bacterial Endophytes. In: Microbial Root Endophytes (Schulz B, Boyle C and Sieber TN, eds.). Springer-Verlag, Berlin, 53-66.

Brunetta JMFC, Alfenas AC, Mafia RG and Gomes JM (2007). Avaliação da especificidade de rizobactérias isoladas de diferentes espécies de Pinus sp. Rev. Árvore 31: 1027-1033.

Chanway CP (1998). Bacterial endophytes: ecological and practical implications. Sydowia 50: 149-170.

Chun J and Bae KS (2000). Phylogenetic analysis of Bacillus subtilis and related taxa based on partial gyrA gene sequences. Antonie van Leeuwenhoek 78: 123-127.

Dias ACF, Costa FEC, Andreote FD, Lacava PT, et al. (2009). Isolation of micropropagated strawberry endophytic bacteria and assessment of their potential for plant growth promotion. World J. Microbiol. Biotechnol. 25: 189-195.

Díaz K, Valiente C, Martínez M, Castillo M, et al. (2009). Root-promoting rhizobacteria in Eucalyptus globules cuttings. World J. Microbiol. Biotechnol. 25: 867-873.

Dickson A, Leaf AL and Hosner JF (1960). Quality appraisal of white spruceand white pine seedling stock in nurseries. Forest. Chron. 36: 10-13.

Döbereiner J, Baldani VLD and Baldani JI (1995). Como Isolar e Identificar Bactérias Diazotróficas de Plantas NãoLeguminosas. EMBRAPA-CNPAB, Rio de Janeiro.

Dyszynski G and Sheldon W (2011). RDPquery: A Java Program from the Sapelo Program Microbial Observatory for Automatic Classification of Bacterial 16S rRNA Sequences Based on Ribosomal Database Project Taxonomy and Smith-Waterman Alignment. Avaliable at [http://simo.marsci.uga.edu/public_db/rdp_query.htm]. Accessed September 15, 2011.

Ferreira A (2008). Interação Entre Bactérias Endofíticas e do Rizoplano com Eucalyptus. Master's thesis, Escola Superior de Agricultura "Luiz de Queiroz", USP, Piracicaba.

Ferreira A, Quecine MC, Lacava PT, Oda S, et al. (2008). Diversity of endophytic bacteria from Eucalyptus species seeds and colonization of seedlings by Pantoea agglomerans. FEMS Microbiol. Lett. 287: 8-14.

Kimura M (1980). A simple method for estimating evolutionary rates of base substitutions through comparative studies of nucleotide sequences. J. Mol. Evol. 16: 111-120. 
Kuklinsky-Sobral J, Araujo WL, Mendes R, Geraldi IO, et al. (2004). Isolation and characterization of soybean-associated bacteria and their potential for plant growth promotion. Environ. Microbiol. 6: 1244-1251.

Lis JT (1980). Fractionation of DNA fragments by polyethylene glycol induced precipitation. Methods Enzymol. 65: 347-353.

Lombard L, Zhou XD, Crous PW, Wingfield BD, et al. (2010). Calonectria species associated with cutting rot of Eucalyptus. Persoonia 24: 1-11.

Long HH, Schmidt DD and Baldwin IT (2008). Native bacterial endophytes promote host growth in a species-specific manner; phytohormone manipulations do not result in common growth responses. PLoS One 3: e2702.

Mafia RG, Alfenas AC, Ferreira EM, Zarpelon TG, et al. (2005). Crescimento de mudas e produtividade de minijardins clonais de eucalipto tratados com rizobactérias selecionadas. Rev. Árvore 29: 843-851.

Nautiyal CS (1999). An efficient microbiological growth medium for screening phosphate solubilizing microorganism. FEMS Microbiol. Lett. 170: 265-270.

Nunes FV (2004). Isolamento e Identificação de Bactérias Endofíticas de Café (Coffea arabica e Coffea robusta) e suas Aplicações Biotecnológicas. Master's thesis, Universidade de São Paulo, São Paulo.

Patten CL and Glick BR (2002). Role of Pseudomonas putida indoleacetic acid in development of the host plant root system. Appl. Environ. Microbiol. 68: 3795-3801.

Procópio REL (2004). Diversidade de Bactérias Endofíticas de Eucalyptus spp. e Avaliação do seu Potencial Biotecnológico. Doctoral thesis, Escola Superior de Agricultura "Luiz de Queiroz", USP, Piracicaba.

Procópio REL, Araujo WL, Maccheroni W Jr and Azevedo JL (2009). Characterization of an endophytic bacterial community associated with Eucalyptus spp. Genet. Mol. Res. 8: 1408-1422.

Rodriguez RJ, White JF Jr, Arnold AE and Redman RS (2009). Fungal endophytes: diversity and functional roles. New Phytol. 182: 314-330.

Saitou N and Nei M (1987). The neighbor-joining method: a new method for reconstructing phylogenetic trees. Mol. Biol. Evol. 4: 406-425.

Sambrook J, Fritschi EF and Maniatis T (1989). Molecular Cloning: A Laboratory Manual. Cold Spring Harbor Laboratory Press, New York.

Shi Y, Lou K and Li C (2009). Promotion of plant growth by phytohormones-producing endophytic microbes of sugar beet. Biol. Fertil. Soils 45: 645-653.

Strobel GA (2002). Rainforest endophytes and bioactive products. Crit. Rev. Biotechnol. 22: 315-333.

Tamura K, Dudley J, Nei M and Kumar S (2007). MEGA4: molecular evolutionary genetics analysis (MEGA) software version 4.0. Mol. Biol. Evol. 24: 1596-1599.

Unterseher M, Reiher A, Finstermeier K and Otto P (2007). Species richness and distribution patterns of leaf-inhabiting endophytic fungi in a temperate forest canopy. Mycol. Prog. 6: 201-212.

Verma VC, Gond SK, Kumar A, Kharwar RN, et al. (2007). The endophytic mycoflora of bark, leaf, and stem tissues of Azadirachta indica A. Juss (neem) from Varanasi (India). Microb. Ecol. 54: 119-125.

Wang H, Wen K, Zhao X, Wang X, et al. (2009). The inhibitory activity of endophytic Bacillus sp. strain CHM1 against plant pathogenic fungi and its plant growth-promoting effect. Crop Protect. 28: 634-639. 